RFP-2206

May 27, 1974

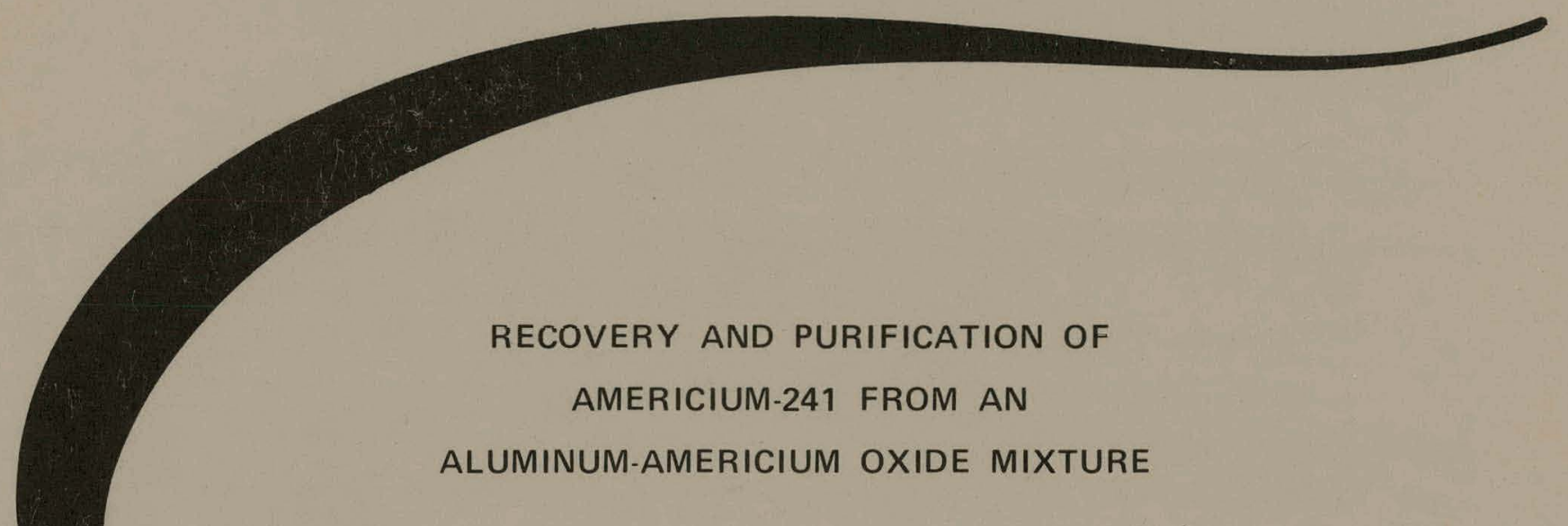

Stephen G. Proctor

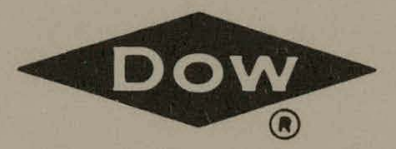

DOW CHEMICAL U.S.A. ROCKY FLATS DIVISION

P. O. BOX 888

GOLDEN, COLORADO 80401

U. S. ATOMIC ENERGY COMMISSION CONTRACT AT(29-1)-1106 


\section{DISCLAIMER}

This report was prepared as an account of work sponsored by an agency of the United States Government. Neither the United States Government nor any agency Thereof, nor any of their employees, makes any warranty, express or implied, or assumes any legal liability or responsibility for the accuracy, completeness, or usefulness of any information, apparatus, product, or process disclosed, or represents that its use would not infringe privately owned rights. Reference herein to any specific commercial product, process, or service by trade name, trademark, manufacturer, or otherwise does not necessarily constitute or imply its endorsement, recommendation, or favoring by the United States Government or any agency thereof. The views and opinions of authors expressed herein do not necessarily state or reflect those of the United States Government or any agency thereof. 


\section{DISCLAIMER}

Portions of this document may be illegible in electronic image products. Images are produced from the best available original document. 


\section{LEGAL NOTICE}

This report was prepared as an account of work sponsored by the United States Government. Neither the United States nor the United States Atomic Energy Commission, nor any of their employees, nor any of their contractors, subcontractors, or their employees, makes any warranty, expressed or implied, or assumes any legal liability or responsibility for the accuracy, completeness or usefulness of any information, apparatus, product or process disclosed, or represents that its use would not infringe privately owned rights.

Printed in the United States of America

Available from the

National Technical Information Service

U. S. Department of Cummerce Springfield, Virginia 22151

Price: Printed Copy $\$ 4.00$ Microfiche $\$ 1.45$ 
Printed

May 27, 1974
RFP-2206

UC-4 CHEMISTRY

TID-4500-R60

\section{RECOVERY AND PURIFICATION OF AMERICIUM-241 FROM AN \\ ALUMINUM-AMERICIUM OXIDE MIXTURE}

Stephen G. Proctor

Chemistry Research and Development

CHEMICAL TECHNOLOGY

DOW CHEMICAL U.S.A.

ROCKY FLATS DIVISION

P. O. BOX 888

GOLDEN, COLORADO 80401

Prepared under Contract AT(29-1)-1106

for the

Albuquerque Operations Office

U.S. Atomic Energy Commission
SUBJECT DESCRIPTORS

Aluminum Americium Dissolutinn Purification

Recovery
This report was prepared as

sponsored by the United stas an account of work the United States nor the United Government. Neither Commission, nor any of their Elates Alumle Entergy their contractors, subontactor makes any warranty, legal liability or responsibility implied, or assumes any pleteness or usefulpess of any for the accuracy, comproduct or process discosed any information, apparatus, would not infringess disclosed, or represents that its use 
RFP-2206

$$
1
$$

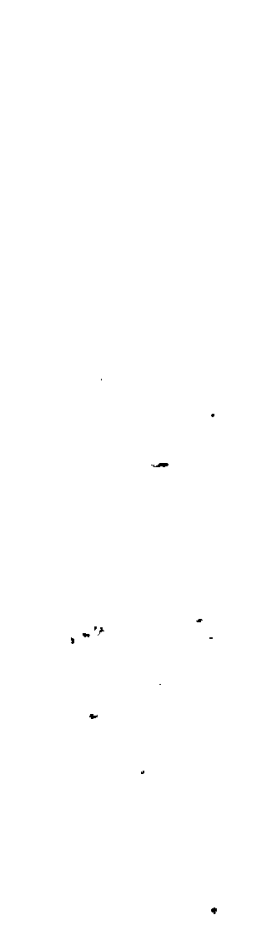




\section{CONTENTS}

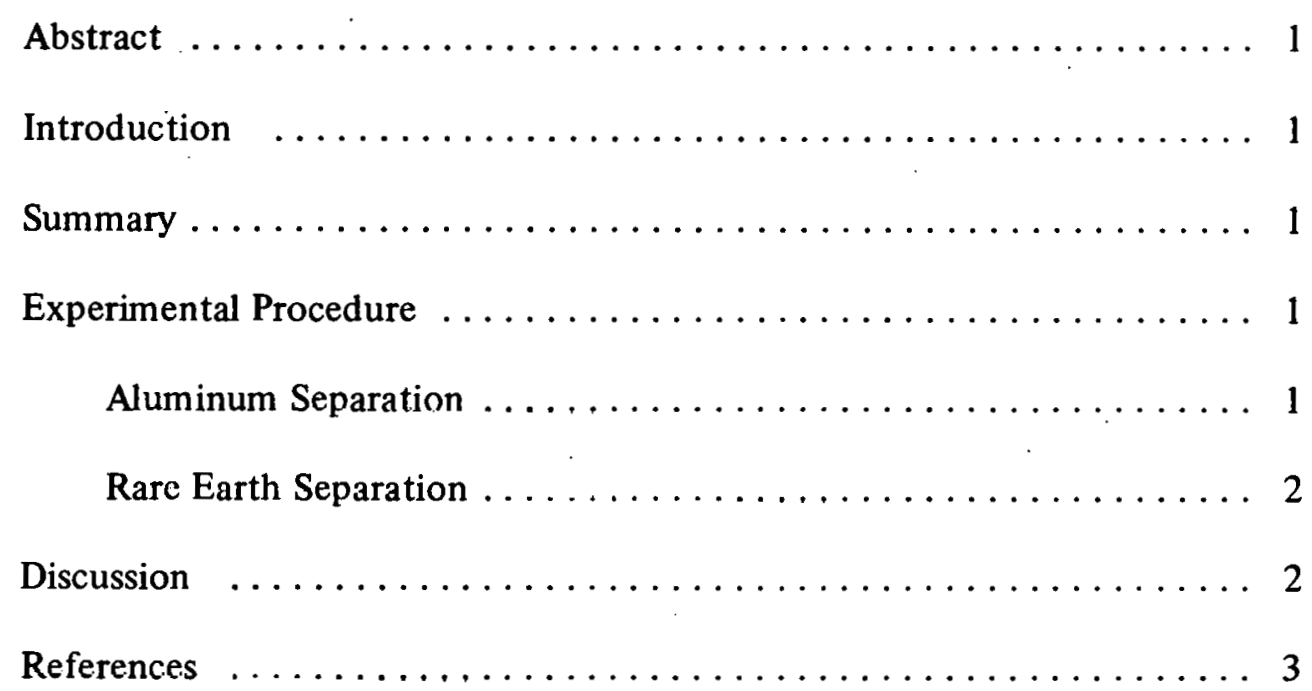


RFP-2206 


\title{
RECOVERY AND PURIFICATION OF \\ AMERICIUM-241 FROM AN \\ ALUMINUM-AMERICIUM OXIDE MIXTURE
}

\author{
Stephen G. Proctor
}

\begin{abstract}
A method for the separation and purification of americium from a mixture of aluminum and americium oxide has been developed. The precipitation procedure was designed to recover americium from gross amounts of aluminum by utilizing aluminum solubility in caustic solutions. Additional purification was obtained by successive fluoride and oxalate precipitations. The developed procedure has been used to recover and purify $57 \mathrm{~g}$ of americium from $204 \mathrm{~g}$ of aluminum-americium oxide.
\end{abstract}

\section{INTRODUCTION}

A simple recovery procedure has been devised to recover americium-241 from a composite of aluminum powder metal and americium oxide. Approximately $57 \mathrm{~g}$ of americium- 241 have been recovered in purified oxide form from a $204-\mathrm{g}$, aluminum-americium oxide mixture. The basic recovery and purification scheme involved dissolving aluminum metal away from the americium oxide using sodium hydroxide, then purifying the recovered americium oxide by successive fluoride and oxalate precipitations. The caustic aluminum-dissolution step was selected based upon previous experience at Savannah River Laboratory ${ }^{1}$ and Rocky Flats where plutonium=aluminum residues were. processed for plutonium recovery.

\section{SUMMARY}

A composite mixture of aluminum metal and americium oxide was processed using a described procedure for recovery and purification of the americium. An americium recovery of $96.3 \%$ was realized from the processing. The $\mathrm{AmO}_{2}$ product contained only $920 \mathrm{ppm}$ of detectable impurities as determined by optical emission spectroscopy.

\section{EXPERIMENTAL PROCEDURE}

\section{Aluminum Separation}

A 2-liter solution of 5-M NaOH made 1-M in $\mathrm{NaNO}_{3}$ was prepared for dissolving the $\mathrm{Al}-\mathrm{AmO}_{2}$ material. The solution was placed in a resin reaction kettle and $\mathrm{Al}-\mathrm{AmO}_{2}$ powder was slowly added. A total of $204.1 \mathrm{~g}$ of $\mathrm{Al}-\mathrm{AmO}_{2}$ mixture was added and the solution then allowed to cool. After cooling, the solution was filtered to remove the insoluble $\mathrm{AmO}_{2}$. The $\mathrm{AmO}_{2}$ was dried and weighed, and the filtrate from the dissolution was sampled for americium content. The dried $\mathrm{AmO}_{2}(103.2 \mathrm{~g})$ was dissolved in 1 liter of $10-\mathrm{M} \mathrm{HNO}_{3}$ by heating the solution to $95^{\circ} \mathrm{C}$ for 2 hours. After the dissolution was complete, acidity of the solution was adjusted to $0.1-\mathrm{M}\left(\mathrm{H}^{+}\right)$by adding $8-\mathrm{M} \mathrm{NH}_{4} \mathrm{OH}$. Sufficient oxalic açid. was added to precipitate the americium and leave the solution $0.1-\mathrm{M}$ in oxalic acid. The resulting slurry was digested at $60^{\circ} \mathrm{C}$ for 30 minutes followed by a 16 -hour digestion period at $20^{\circ} \mathrm{C}$. The solution was then filtered to remove the insoluble americium oxalate $\left(\mathrm{Am}_{2}\left[\mathrm{C}_{2} \mathrm{O}_{4}\right]_{3}\right)$. The oxalate cake was washed with water and calcined at $600{ }^{\circ} \mathrm{C}$ for 6 hours to form $\mathrm{AmO}_{2}$. The calcined $\mathrm{AmO}_{2}$ was then weighed and sampled for americium content and impurity concentrations. 


\section{Rare Earth Separation}

The aluminum-free $\mathrm{AmO}_{2}$ (69.9 g) was divided into three, approximately equal batches in preparation for rare-earth separation. The three batches of $\mathrm{AmO}_{2}$ were each dissolved in $200 \mathrm{ml}$ of $10-\mathrm{M}$ $\mathrm{HNO}_{3}$ and processed identically. The acidity of each solution was reduced to $0.1-\mathrm{M}\left(\mathrm{H}^{+}\right)$by adding 8- $\mathrm{M} \mathrm{NH}_{4} \mathrm{OH}$. The solutions were then heated to $80^{\circ} \mathrm{C}$ and made $0.25-\mathrm{M}$ in ammonium persulfate $\left(\left[\mathrm{NH}_{4}\right]_{2} \mathrm{~S}_{2} \mathrm{O}_{8}\right)$ and $0.002-\mathrm{M}$ in argentic oxide $\left(\mathrm{Ag}_{2} \mathrm{O}\right)$. After digesting the solutions at $80^{\circ} \mathrm{C}$ for 45 minutes, the solutions were made $0.2-\mathrm{M} \mathrm{HF}$ and allowed to digest for five minutes before filtering. The insoluble rare-earth fluoride precipitate was washed with water, dried, and weighed. The three fluoride residues were combined and sampled for americium content. Americium in the resulting filtrate was then reduced to the trivalent state by adding ascorbic acid until the brown color of the hexavalent americyl ion disappeared.

The filtrate containing the americium was precipitated with oxalic acid using the method previously described. The three batches of americium oxalate were calcined to $\mathrm{AmO}_{2}$ and composited. The resulting $\mathrm{AmO}_{2}$ was redissolved in $500 \mathrm{ml}$ of $8-\mathrm{M} \mathrm{HNO}_{3}$ in preparation for the silver and lead removal. The silver and lead were precipitated by making the solution U.1-M in $\mathrm{NH}_{4} \mathrm{Cl}$, thereby forming insoluble $\mathrm{PbCl}_{2}$ and $\mathrm{AgCl}$. The insoluble chloride precipitate was tiltered from the solution, washed with water, and discarded. The americium in the resulting filtrate was again precipitated and the resulting $\mathrm{Am}_{2}\left(\mathrm{C}_{2} \mathrm{O}_{4}\right)_{3}$ calcined to $\mathrm{AmO}_{2}$. The purified $\mathrm{AmO}_{2}$ was weighed and sampled for an impurity analysis and calorimetric americium assay.

\section{DISCUSSION}

Selective aluminum dissolution was successful because of the amphotericity of aluminum and the insolubility of $\mathrm{AmO}_{2}$ in caustic solutions. The aluminum forms an aluminate complex, $\mathrm{Al}(\mathrm{OH})_{4}^{-}$, in the dissolving reaction as shown by Equation 1 .

$$
\mathrm{Al}+4 \mathrm{NaOH} \rightarrow \mathrm{Al}(\mathrm{OH})_{4}^{-}+4 \mathrm{Na}^{+}
$$

The total reaction is shown in Equation 2.

$$
\begin{aligned}
\mathrm{Al}+\mathrm{NaOH}+3 \mathrm{H}_{2} \mathrm{O} \rightarrow \mathrm{Al}(\mathrm{OH})^{-}{ }_{4} & \\
& +\mathrm{Na}^{+}+3 / 2 \mathrm{H}_{2} \uparrow
\end{aligned}
$$

The evolution of hydrogen gas was suppressed by the addition of sodium nitrate, which reacts as shown in Equation 3.

$$
\mathrm{NO}_{3}^{-\infty}+3 \mathrm{H}^{+}+2 \mathrm{e}^{-} \rightarrow \mathrm{HNO}_{2}+\mathrm{H}_{2} \mathrm{O}
$$

This reaction prevents accumulation of a potentially hazardous hydrogen-oxygen mixture during the dissolution step.

The aluminum dissolution was vigorous but was controlled by limiting the addition of aluminumamericium oxide feed material. After the aluminum was dissolved, the insoluhle. $\mathrm{AmO}_{2}$ was easily separated from the solution by filtration. The $\mathrm{AmO}_{2}$ was then dissolved in nitric acid in preparation for precipitation of americium as americium oxalate. This precipitation further reduced the aluminum contamination in the americium product. The americium oxalate was then calcined to $\mathrm{AmO}_{2}$, which was analyzed for impurities. Analysis showed the aluminum concentration was reduced from an initial concentration of $65.6 \mathrm{wt} \%$ to 0.02 wt $\%$. Other impurities were mainly rare earths $(7000 \mathrm{ppm})$ as shown in Table 1.

The rare-earth impurities were removed by fluoride precipitation; ${ }^{2}$ however, americium was maintained in solutinn hy heing nxidized to the hexavalent state (Am VI). Trivalent americium will precipitate along with rare earths so complete oxidation of the americium was essential for a high recovery of americium. Oxidation was carried out in dilute nitric acid with ammonium 
Table 1. Detectable Impurities in Americium Oxide After Aluminum Separation.

\begin{tabular}{|c|c|}
\hline Element & $\begin{array}{c}\text { Concentration } \\
(\mathrm{ppm})^{*}\end{array}$ \\
\hline Al & 200 \\
\hline $\mathrm{Ca}$ & 150 \\
\hline $\mathrm{Cu}$ & 100 \\
\hline $\mathrm{Fe}$ & 300 \\
\hline $\mathrm{Ce}$ & 5000 \\
\hline Nd & 500 \\
\hline $\mathrm{Tm}$ & 500 \\
\hline Y & 1000 \\
\hline TOTAL & 7750 \\
\hline
\end{tabular}

*ppm $-\mu \mathrm{g}$ of impurity element per gram of $\mathrm{AmO}_{2}$.

persulfate by heating the solution to $80^{\circ} \mathrm{C}$ for 45 minutes. Argentic oxide was added as a holding oxidant. The addition of fluoride ion (HF) caused the rare-earth fluorides to precipitate while the americium VI remained soluble. The rare-earth fluoride material was separated from the americium by filtration and checked for amsicium sontent.

The americium-bearing filtrate was again precipitated with oxalic acid and the resulting americium oxalate calcined to $\mathrm{AmO}_{2}$. The $\mathrm{AmO}_{2}$ product was analyzed for impurities as shown in Table 2 . Results of rare-earth separation from americium showed the rare earths were reduced from 7000 $\mathrm{ppm}$ to $50 \mathrm{ppm}(\mathrm{Tm})$ with a single precipitation. The $\mathrm{AmO}_{2}$ product, calorimetrically assayed for americium content, had $0.875 \mathrm{~g} \mathrm{Am} / \mathrm{g} \mathrm{AmO}_{2}$.

Recovery of americium as purc $\mathrm{AmO}_{2}$ totaled $96.3 \%$, which was considered excellent. Most of
Table 2. Detectable Impurities in the Americium Oxide Product.

\begin{tabular}{cc} 
Element & $\begin{array}{c}\text { Concentration } \\
(\mathrm{ppm})^{*}\end{array}$ \\
\cline { 2 - 2 } $\mathrm{Al}$ & 20 \\
$\mathrm{Ca}$ & 500 \\
$\mathrm{Cr}$ & 50 \\
$\mathrm{Cu}$ & 100 \\
$\mathrm{Fe}$ & 100 \\
$\mathrm{Si}$ & 100 \\
$\mathrm{Tm}$ & 50 \\
TOTAL & 920
\end{tabular}

${ }^{*} \mathrm{ppm}-\mu \mathrm{g}$ of impurities per gram of $\mathrm{AmO}_{2}$.

the lost americium was in the rare-earth fluoride precipitate. The filtrate from the caustic dissolution contained 1:85 $\times 10^{-4} \mathrm{~g} \mathrm{Am} /$ liter of solution; the oxalate filtrate contained $6.4 \times 10^{-3} \mathrm{~g} \mathrm{Am} /$ liter of solution. Both filtrates were subsequently discarded.

\section{REFERENCES}

1. W. C. Perkins; "Dissolution of Pu-Al Alloy," E. I. DuPont de Nemours and Co., Savannah River Laboratory, Aiken, South .Carolina, USAEC Report DP-702 (1962).

2. S. G. Proctor, "Rare Earth Removal from Americium Oxide," U. S. Patent 3,723,594, May 18, 1972. 
RFP-2206 